Article

\title{
Is Private Entrepreneurs' Religiosity Conducive to Environmental Investment? Evidence from China
}

\author{
Sheng Yao * (D) and Weiwei Zhang \\ School of Management, China University of Mining and Technology, Xuzhou 221116, China; \\ 09134115@cumt.edu.cn \\ * Correspondence: kj9704@126.com; Tel.: +86-1377-597-8061
}

Received: 25 December 2019; Accepted: 14 February 2020; Published: 16 February 2020

\begin{abstract}
With data from the 2010 Chinese Private Enterprises Survey (CPES), we provide direct and robust evidence that private entrepreneurs' religiosity is conducive to firm environmental investment, and that the presence of elder or male private entrepreneurs tends to strengthen this improvement effect significantly. Further evidence shows that private entrepreneurs adhering to one of the Asian religions has a more significant influence on the increase of environmental investment. Our results could help to improve firm environmental investment and regional environmental quality.
\end{abstract}

Keywords: religious belief; firm environmental investment; private entrepreneur

\section{Introduction}

Based on organizational legitimacy theory, resource-based theory, and stakeholder theory [1-3], existing studies have found that external factors, such as the degree of environmental control, likelihood of an environment regulatory change, industry concentration, consumers' green preferences, and media coverage [4-6], as well as specific firm-level characteristics, such as firm size, firm age, industry, financial conditions, and R\&D intensity [7-9], can affect firm environmental investment. However, the influence of entrepreneurs' personal characteristics on firm environmental investment has been largely ignored by researchers. Some studies have explored the role that entrepreneurs' attitudes, perceptions, and supportive actions play in corporate environmental strategies [10,11] and decision-making processes [12]. Religion is another important factor that affects entrepreneurs' attitudes, perceptions, and supportive actions [13]. Prior studies have shown that religiosity is positively associated with risk aversion $[14,15]$. Religious belief works as a paradigm through which individuals observe, understand, interpret, and evaluate their experiences and direct their behaviors.

In an emerging and transitional country such as China, formal institutions, such as the legal system and market rules, are less developed and informal institutions play an alternative governance role. Williamson argues that informal institutional arrangements such as culture and religion have an important impact on formal systems [16]. Religion has an influence on manager behavior and on firm behavior [17-19]. We examine the influence of entrepreneurs' religious beliefs on firm environmental investment with data from the 2010 Chinese Private Enterprises Survey (CPES). We find strong and robust evidence that entrepreneurs' religiosity is conducive to firm environmental investment, and that other characteristics of entrepreneurs, such as being elder or male, interactively strengthen their firm environmental investment level. In addition, we also find that entrepreneurs who adhere to one of the Asian religions have a more significant influence on the improvement of firm environmental investment compared with entrepreneurs who adhere to one of the non-Asian religions. Our study shows the effect of informal institutions on the environmental investment of private firms. In practice, entrepreneurs should be encouraged to affiliate with religiosity, which can help them emphasize environmental responsibility and undertake more environmental investment to improve environmental quality. 
Our study contributes to the environmental literature in two ways. On the one hand, we examine the influence of private entrepreneurs' religiosity on firm environmental decision-making in the institutional setting of China. Many studies show that religious diversity has both positive and negative effects on economic growth and regional development $[20,21]$. However, few studies have empirically investigated the environmental effect of Asian religions on firm environmental investment. In fact, environmental investment depends more on entrepreneurs' views on the importance of the environment than on other factors, and religion may help entrepreneurs establish this view, in addition to their personality, education, and neurological structure [22,23]. We thus analyze the mechanisms of the influence of religiosity on micro corporate decisions, and find that self-worth orientation theory can explain the influence of entrepreneurs' religiosity on firm environmental investment. On the other hand, we examine the effect of personal religiosity on corporate decisions on environmental investment. The effect of religion at the individual and country levels has been well studied [24]; however, there is little empirical research on how personal religious beliefs affect corporate decisions. Based on CPES (2010), we provide evidence of the effect that religiosity may have on the environment, and accurately describe entrepreneurs' individual religiosity. Thus, our empirical evidence is more direct and reliable.

The remainder of our paper is organized as follows. Section 2 reviews the theoretical analysis and develops the research hypotheses. Section 3 describes the sample, variable measurement, and research design. Section 4 presents the empirical results and robustness checks. Section 5 concludes the paper.

\section{Theoretical Analysis and Development of Hypotheses}

\subsection{The Effect of Entrepreneurs' Individual Religiosity on Firm Environmental Investment}

There are two theories that can explain the effect of entrepreneurs' individual religiosity on firm environmental investment. One is the upper echelons theory, which suggests that the life experience of entrepreneurs is causally linked with their unique personal values and traits, which in turn affect their management styles and lead to different organizational outcomes [25]. Individual religiosity is an important life experience and it directly affects decision-making on environmental investment. Another is the self-worth orientation theory, which holds that people's actual behavior is subject to two factors: attitude of an inner preparatory state, and the pressure of the external situation. When the external pressure is relatively stable, whether the attitude itself is at the center of the individual's value system determines the consistency between their attitude and specific behaviors [26]. For instance, the improvement and amendment of laws and regulations related to environmental protection take quite a long time, so external pressure from formal systems on entrepreneurs may be relatively stable. In this situation, if entrepreneurs value environmental responsibility enough, they would take specific actions to promote it, such as improving the level of firm environmental investment. Compared with nonreligious entrepreneurs, religious entrepreneurs pay more attention to corporate environmental responsibility under the influence of religious doctrines. This attitude, which is closer to the center of an individual value system, prompts entrepreneurs to take concrete action to fulfill environmental responsibility and improve environmental investment. Iannaccone holds that one's religious beliefs can affect and explain his or her economic attitudes, behaviors, and decisions [26]. Park also documented religion as a meaning system that shapes individuals' values and directs their behaviors [13]. There are some ecological ethics in religious doctrines, which can prompt entrepreneurs to attach great importance to environmental responsibility. Moreover, there are some precepts against killing, for liberating the living, and for living a vegetarian lifestyle in Buddhism. Some of these doctrines are helpful for ecological balance, wildlife protection, and environmental protection. Some beliefs and practices underlying Taoism are also supportive of environmental conservation. For example, the teachings of the "imitation of nature" and "unity of man and nature" emphasize that humans should live harmoniously with nature and be subject to nature in the manner of non-action. The Bible says, "using a pure heart devoted to God to love all things that are with you", which holds that both human beings and nature are created by God and that human beings 
have the responsibility to protect nature. Similarly, in the eyes of Muslims, "all things in the world are created by Allah". Human beings are not superior rulers but are created by Allah together with all other things, and they are equal. Therefore, human beings should respect nature and protect ecology; if humans do not protect the environment, they will suffer from disasters and be punished by Allah. Catholicism believes that "human beings are not the right masters of nature, but the custodians of God. Respect for nature is also respect for the creators of nature. In nature, all kinds of creatures depend on and interact with each other. There should be a moral standard for the use of natural objects." Though there may be a discrepancy between lofty ideals and actual lived practices, religious entrepreneurs tend to be affected by these religious doctrines. With the influence of ecological ethics in religious culture, the attitude of respecting, conforming to, and protecting nature may become a part of these entrepreneurs' self-worth systems. Compared with non-religious entrepreneurs, the attitude of "environmental protection" is closer to the central position of religious entrepreneurs' hierarchy of values. Under the influence of the orientation effect of the self-worth system, entrepreneurs may carry out "corporate environmental protection" more actively. Entrepreneurs may fulfill corporate environmental responsibility in various ways, such as installing environmental protection equipment, reducing pollutant emissions, increasing environmental greening in the plant area, publicly disclosing environmental information, and participating in environmental public welfare activities. Among these, we predict that increasing environmental investment may have the most economic and social benefits, and is the most frequently implemented action undertaken by entrepreneurs.

In addition, religions urge believers to scrupulously abide by their rules, and this reduces the possibility of religious entrepreneurs disregarding environmental responsibilities. When making decisions on environmental protection investment, religious entrepreneurs are not only restricted by laws and regulations related to environmental regulation, but are also likely to be affected by the dogmas and rules of the religion that they are affiliated with. As mentioned above, many religious doctrines tend to emphasize that humans should protect nature and have no right to arbitrarily control and destroy nature. At the same time, the existence of an omniscient God in the religious world, and the concepts of "afterlife" and "heaven", strengthen the above constraints. The former means that violations of the rules may inevitably be observed, while the latter means that the cost of violating the rules may be increased. Religions provide constraints beyond the formal system, so that religious private entrepreneurs improve themselves to a greater degree and more strictly abide by relevant laws and regulations regarding the environment. We predict that firms with religious entrepreneurs will be more likely to engage in environmental investment, leading to our first hypothesis.

Hypothesis 1. Entrepreneurs' individual religiosity is positively associated with firm environmental investment.

\subsection{The Moderating Effect of Entrepreneurs' Other Characteristics on the Relationship between Entrepreneurs' Individual Religiosity and Firm Environmental Investment}

If Hypothesis 1 is valid, then the effects of religions do vary across entrepreneurs' age and gender. Hambrick and Mason highlighted the critical role of entrepreneurs in corporate decision making [25]. The characteristics of entrepreneurs that can be observed (age, gender, educational background, etc.) are proxy variables for cognition, preferences, values, and other psychological dimensions of managers $[27,28]$. The self-worth orientation theory also emphasizes the orientation effect of the individual's self-worth system on behavior, and believes that the consistency of values and behavior is moderated by how close such an attitude is to the individual's core values. In other words, behaviors are highly consistent with an attitude that is very close to the individual's core values. Instead, if the attitude is not close to the individual's core values, the relevant behaviors are most likely driven by pressure from the external situation.

Age plays an important role in shaping the perception of entrepreneurs, and entrepreneurs of different ages make different environmental decisions. Trevino found that the level of cognitive moral 
development improves from middle childhood to adulthood, and that moral development involves the individual's passage, step by step, in an invariant irreversible sequence [29]. The cognition around environmental issues improves as age increases. Presumably, along with the increase of age, the "environmental protection" attitude is closer to entrepreneurs' core values, thus strengthening the self-worth orientation effect. First, young entrepreneurs are willing to take risks and expect firms to grow rapidly. They may pay close attention to increases in stock prices, but not to firm environmental responsibility. By contrast, elder entrepreneurs are more prudent and conservative, focusing on the long-term growth of firms. They try to avoid risky actions that may undermine existing interests, and actively focusing on environmental responsibility is a less perilous decision. Second, in accordance to Maslow's hierarchy of needs, as elder entrepreneurs accumulate a certain amount of wealth and achieve a certain social status, they may have successfully fulfilled lower-level needs. Their behavior is thus largely driven by self-actualization needs, so they may be willing to take on environmental responsibility to burnish their personal reputation and achieve their own values and social recognition. Third, the development of firms is inseparable from the support of all sectors of society. As a firm grows and the entrepreneur's age increases, the entrepreneur is more capable of and willing to repay society. He or she tends to be more active in fulfilling firm environmental responsibility. If the entrepreneurs' religiosity is conducive to firm environmental investment under the orientation effect of the self-worth system, then their positive relationship will be more significant for firms with elder religious entrepreneurs, inspiring us to construct our second hypothesis.

Hypothesis 2. The positive association between entrepreneurs' religiosity and firm environmental investment is stronger for firms with elder entrepreneurs.

In terms of the influence of entrepreneurial gender differences on corporate social responsibility decision-making, researchers have found that female CEOs and directors can significantly promote corporate social performance [30,31], because corporate social performance originates from environmental investment. Accordingly, we predict that the positive association between entrepreneurs' religiosity and firm environmental investment will be stronger for firms with female religious entrepreneurs. Compared with male entrepreneurs, some female entrepreneurs hold an "environmental protection" attitude that is closer to their core values. In the existing literature, women play an important role in management decisions. First, women's preferences for risk aversion may encourage them to take an active part in firm environmental responsibility. Second, women have a stronger sense of compliance with discipline and legality, and may enhance the legitimacy of firms by improving the level of firm environmental investment. Third, women are more meticulous and empathetic, so they pay greater attention to social problems and value environmental responsibility, and thus, their companies may have better environmental performance. From this perspective, women's "environmental protection" attitude may be relatively closer to their core values, thus strengthening the self-worth orientation effect. We predict that the positive association between entrepreneurs' religiosity and firm environmental investment is stronger for firms with female religious entrepreneurs.

However, existing studies have not drawn a consistent conclusion in this area. Williams noted that there is no link between women board members and firms that support education or public policy issues [32]. Bowen and Hisrich point out that successful female entrepreneurs are more masculine than women in general, so it is difficult to say whether female attributes affect the decision-making of firms [33]. Compared with women, men have a unique nature that drives the "environmental protection" attitude to be closer to their core values. First, environmental investment has a significant positive externality, which may impact shareholders' existing interests, so its implementation will inevitably be impeded. Despite the fact that women today have greater access than ever before to equality, men can still obtain more resources and support from their social networks than women. Men are likewise more confident than women and more likely to carry out environmental investment decisions without fear of objection. In addition, entrepreneurs can raise their profiles by actively undertaking 
firm social responsibility initiatives [32]. Specifically, entrepreneurs strategically give prominence to bearing corporate environmental responsibilities to sharpen their image as environmentally-friendly entrepreneurs, and then earn praise and recognition from the public and society. Researchers note that different genders have different senses of accomplishment. Female entrepreneurs are more likely to set economic needs as entrepreneurial goals [33], while male entrepreneurs value their reputation more. Thus, male entrepreneurs have more motivation to take on environmental responsibilities and improve their firm environmental investment. From this perspective, men's "environmental protection" attitude may be relatively closer to their core values, thus strengthening the self-worth orientation effect. We predict that the positive association between entrepreneurs' religiosity and firm environmental investment is stronger for firms with male religious entrepreneurs. Overall, we formulated two alternative hypotheses.

Hypothesis 3a. The positive association between entrepreneurs' religiosity and firm environmental investment is stronger for firms with female entrepreneurs.

Hypothesis $\mathbf{3 b}$. The positive association between entrepreneurs' religiosity and firm environmental investment is stronger for firms with male entrepreneurs.

\subsection{Effects of Different Types of Religion on Firm Environmental Investment}

Religion in China can be divided into Asian religions and non-Asian religions, depending on where the religious traditions originated. Different religions, which convey different cultural concepts, may have different effects on entrepreneurs. Asian religions and mainland culture influence each other. For instance, in a society dominated by agriculture, the harvest is what people pay the most attention to. Ecological harmony is embodied in the core values of Asian religions, such as Buddhism and Taoism. Presently, this effect still exists. Therefore, entrepreneurs who are affiliated with Asian religions may be more inclined to assume environmental obligations. Non-Asian religions and marine cultures interact with each other. In a society dominated by fisheries, people must fight against the natural environment to obtain food. Compared with Asian religions, non-Asian religions have a relatively weakened awe of nature. From this view, the "environmental protection" attitude of entrepreneurs who are affiliated with an Asian religion may be relatively closer to their core values and thus strengthen the self-worth orientation effect. We predict that compared with entrepreneurs who adhere to non-Asian religions, entrepreneurs who adhere to an Asian religion will have a more significant influence on the improvement of firm environmental investment. Thus, we state our fourth hypothesis.

Hypothesis 4. The positive association between entrepreneurs' religiosity and firm environmental investment is stronger for firms with entrepreneurs who adhere to an Asian religion.

\section{Research Design}

\subsection{Sample Selection}

We used data from the CPES conducted by the Privately Owned Enterprises Research Project Team (member organizations include the All-China Federation of Industry and Commerce, State Administration for Industry and Commerce, China Society of Private Economy, and United Front Work Department of CCP). From the survey results, all of the data needed for the empirical tests were obtained, including the religious beliefs of a sample of private entrepreneurs. To mitigate the influence of outliers, we winsorized all continuous variables at the $1 \%$ and $99 \%$ levels.

Table 1 presents the sample distribution by province. Private firms in the survey came from all 31 of China's provinces. This table shows that the sample distribution is fairly even, as no province contains more than $10 \%$ of the private firms and only six provinces contain more than $5 \%$ of the private firms in our sample. Table 1 also presents the percentage of firms with religious entrepreneurs within 
each province. It is worth noting that $53.85 \%$ of religious entrepreneurs are in Xizang (Tibet), and that other provinces where Tibetans gather (e.g., Yunnan and Qinghai) also have a high percentage of religious entrepreneurs. We treat these provinces as a special case in our subsequent analyses.

Table 1. Sample distribution.

\begin{tabular}{|c|c|c|c|}
\hline Province & Frequency & $\%$ of Total Sample & $\%$ of Religious Entrepreneurs \\
\hline Beijing & 159 & 3.99 & 10.06 \\
\hline Tianjin & 98 & 2.46 & 3.06 \\
\hline Hebei & 137 & 3.44 & 12.41 \\
\hline Shanxi & 83 & 2.08 & 14.46 \\
\hline Neimenggu & 51 & 1.28 & 3.92 \\
\hline Liaoning & 186 & 4.67 & 13.98 \\
\hline Jilin & 129 & 3.24 & 7.75 \\
\hline Heilongjiang & 123 & 3.09 & 15.45 \\
\hline Shanghai & 265 & 6.65 & 24.91 \\
\hline Jiangsu & 337 & 8.46 & 20.47 \\
\hline Zhejiang & 274 & 6.88 & 30.29 \\
\hline Anhui & 102 & 2.56 & 17.65 \\
\hline Fujian & 94 & 2.36 & 70.21 \\
\hline Jiangxi & 43 & 1.08 & 25.58 \\
\hline Shandong & 236 & 5.93 & 13.56 \\
\hline Henan & 86 & 2.16 & 17.44 \\
\hline Hubei & 219 & 5.50 & 13.70 \\
\hline Hunan & 100 & 2.51 & 28.00 \\
\hline Guangdong & 317 & 7.96 & 21.77 \\
\hline Guangxi & 70 & 1.76 & 14.29 \\
\hline Hainan & 76 & 1.91 & 32.89 \\
\hline Chongqing & 133 & 3.34 & 11.28 \\
\hline Sichuan & 154 & 3.87 & 20.13 \\
\hline Guizhou & 118 & 2.96 & 21.19 \\
\hline Yunnan & 75 & 1.88 & 29.33 \\
\hline Xizang & 13 & 0.33 & 53.85 \\
\hline Shanxi & 101 & 2.54 & 11.88 \\
\hline Gansu & 72 & 1.81 & 23.61 \\
\hline Qinghai & 67 & 1.68 & 49.25 \\
\hline Ningxia & 29 & 0.73 & 62.07 \\
\hline Xinjiang & 36 & 0.90 & 19.44 \\
\hline Total & 3983 & 100 & 20.44 \\
\hline
\end{tabular}

\subsection{Variable Measurement}

The explained variable was the level of firm environmental investment (Eninvest). Following Tang et al., Eninvest was calculated as the amount of environmental investment scaled by sales revenue in the current year times 100 [34]. We created a dummy variable, called Religion. Religion was assigned a value of 1 if the entrepreneur was religious, and 0 otherwise. We further divided religion into Asian religions (Religion_A) and non-Asian religions (Religion_N). If the entrepreneur was affiliated with Buddhism or Taoism, Religion_A equaled 1, and was 0 otherwise. If the entrepreneur was affiliated with Islam or Christianity, Religion_N was assigned a value of 1 , and 0 otherwise. Other variables included entrepreneur age (Entrepreneur Age) and entrepreneur gender (Entrepreneur Gender). According to the existing literature [19,35], we also controlled the following variables: controlling shareholders (Largest), firm age (Firm Age), firm size (Firm Size), monetary fund ratio (Cashholding), revenue (Log Sale), year dummy variable (Year), and industry dummy variable (Industry). The specific definitions of each are provided in the Appendix A. 


\subsection{Empirical Models}

To test our hypotheses, H1-H4, we constructed regression Models (1)-(4). To verify the relationship between firm environmental investment and entrepreneur religiosity, we established Model (1).

$$
\text { Eninvest }=\alpha_{0}+\alpha_{1} \text { Religion }+\alpha_{i} \sum \text { Controls }+\varepsilon
$$

To examine whether other characteristics of entrepreneurs strengthen the influence of entrepreneurs' religiosity on environmental investment, we introduced an interactive item between Religion and other characteristics of entrepreneurs (i.e., Entrepreneur Age, Entrepreneur Gender), and constructed Models (2) and (3).

$$
\begin{gathered}
\text { Eninvest }=\alpha_{0}+\alpha_{1} \text { Entrepreneur Age }+\alpha_{2} \text { Religion } \times \text { Entrepreneur Age }+\alpha_{i} \sum \text { Controls }+\varepsilon \\
\text { Eninvest }=\alpha_{0}+\alpha_{1} \text { Entrepreneur Gender }+\alpha_{2} \text { Religion } \times \text { Entrepreneur Gender }+\alpha_{i} \sum \text { Controls }+\varepsilon
\end{gathered}
$$

Furthermore, following Jiang et al., we divided religion into Asian religions (Religion_A) and non-Asian religions (Religion_N) and then ran Model (4) to test the effect of the different types of religion on firm environmental investment [19].

$$
\text { Eninvest }=\alpha_{0}+\alpha_{1} \text { Religion_A }+\alpha_{2} \text { Religion_ } N+\alpha_{i} \sum \text { Controls }+\varepsilon
$$

\section{Empirical Results}

\subsection{Descriptive Statistics}

Table 2A provides summary statistics. The mean of Eninvest is 0.489 , which means that $0.489 \%$ of the company's sales revenue is used for environmental investment. This result indicates that the level of environmental investment of Chinese companies is relatively low. Religion has a mean value of 0.204 , indicating that $20.4 \%$ of entrepreneurs in the sample are religious entrepreneurs. In addition, the mean of Religion_A is 0.171 and the mean of Religion_N is 0.026 , showing that more people are affiliated with an Asian religion than a non-Asian religion in China. Table 2B presents univariate comparisons between firms with religious entrepreneurs and firms with nonreligious entrepreneurs. We found that firms with religious entrepreneurs have a larger mean value of firm environmental investment of 0.132 than firms without religious entrepreneurs. The difference is significant at the $10 \%$ level.

\subsection{Correlations}

Table 3 reports the correlation matrix of the variables used in this study. We can see that the magnitudes of these correlations appear to be economically small, which ensures that multicollinearity will not be a concern when we later use these variables in regression models. Table 3 also indicates that firm environmental investment (Eninvest) and entrepreneurs' religiosity (Religion) are positively correlated and significant at the 10\% level. The correlation coefficient between Eninvest and Religion_A is positively and significant, while Eninvest and Religion_N are not significantly related. 
Table 2. Descriptive statistics.

\begin{tabular}{ccccccccc}
\hline \multicolumn{7}{c}{ Panel A: Full Sample } \\
\hline Variables & $\mathbf{N}$ & Mean & Std. Dev. & Min & Q1 & Median & Q3 & Max \\
\hline Eninvest & 3682 & 0.489 & 1.809 & 0.000 & 0.000 & 0.092 & 0.121 & 14.210 \\
Religion & 3984 & 0.204 & 0.403 & 0.000 & 0.000 & 0.000 & 0.000 & 1.000 \\
Religion_A & 3984 & 0.171 & 0.376 & 0.000 & 0.000 & 0.000 & 0.000 & 1.000 \\
Religion_N & 3984 & 0.026 & 0.160 & 0.000 & 0.000 & 0.000 & 0.000 & 1.000 \\
Entrepreneur Gender & 3971 & 0.845 & 0.362 & 0.000 & 1.000 & 1.000 & 1.000 & 1.000 \\
Entrepreneur Age & 3947 & 45.810 & 8.601 & 25.000 & 40.000 & 46.000 & 52.000 & 67.000 \\
Largest & 3468 & 0.775 & 0.418 & 0.000 & 1.000 & 1.000 & 1.000 & 1.000 \\
Firm age & 3759 & 1.972 & 0.669 & 0.000 & 1.609 & 2.079 & 2.485 & 2.996 \\
Firm Size & 3883 & 3.901 & 1.623 & 0.693 & 2.708 & 3.871 & 5.024 & 7.857 \\
Cashholding & 3980 & 0.469 & 0.391 & 0.000 & 0.100 & 0.400 & 1.000 & 1.000 \\
Log Sale & 3756 & 15.460 & 3.170 & 0.000 & 14.000 & 15.830 & 17.410 & 20.940 \\
\hline Panel B: Descriptive Statistics between Firms with Religion and Firms without Religion \\
\hline Variables & With Religion & Without Religion & Diff. between Subsamples \\
\cline { 2 - 8 } & Mean & Median & Mean & Median & Mean & Median \\
\hline Eninvest & 0.594 & 0.101 & 0.462 & 0.082 & $0.132 *$ & $0.019 * * *$ \\
Entrepreneur Gender & 0.840 & 1.000 & 0.847 & 1.000 & -0.007 & 0.000 \\
Entrepreneur Age & 45.930 & 46.000 & 45.780 & 46.000 & 0.150 & 0.000 \\
Largest & 0.779 & 1.000 & 0.774 & 1.000 & 0.005 & 0.000 \\
Firm age & 2.054 & 2.197 & 1.952 & 2.079 & $0.102 * * *$ & $0.1188^{* * *}$ \\
Firm Size & 4.141 & 4.094 & 3.839 & 3.829 & $0.302 * * *$ & $0.265 * * *$
\end{tabular}

The symbols ${ }^{* * *}$ and ${ }^{*}$ indicate significance at the $1 \%$ and $10 \%$ level, respectively.

\subsection{Main Results}

\subsubsection{Effect of Entrepreneurs' Individual Religiosity on Firm Environmental Investment}

Table 4 presents the results of the estimated relationship between firm environmental investment and entrepreneurs' individual religiosity, as specified in Model (1). Column (1) does not include control variables, and Column (2) is not controlled for the industry and year fixed effect. We include all of the identified determinants of firm environmental investment in Column (3). The results indicate that entrepreneurs' religiosity is conducive to the level of firm environmental investment, providing strong support for Hypothesis 1.

4.3.2. Moderating Effect of Entrepreneurs' Characteristics on the Relationship between Entrepreneurs' Individual Religiosity and Firm Environmental Investment

Table 5 presents the regression results of Model (2) to test H2. In all columns, the coefficients of the interaction term (Religion $\times$ Entrepreneur Age) are all positive and significant at the $10 \%$ level. The results indicate that the elder the entrepreneur, the higher the level of firm environmental investment. In other words, the positive association between entrepreneurs' religiosity and firm environmental investment is strengthened for firms with elder entrepreneurs, which verifies H2. 
Table 3. Correlations.

\begin{tabular}{|c|c|c|c|c|c|c|c|c|c|c|c|}
\hline Variables & 1 & 2 & 3 & 4 & 5 & 6 & 7 & 8 & 9 & 10 & 11 \\
\hline 1 Eninvest & 1 & 0.030 & $0.039 * *$ & -0.009 & $0.063^{* * *}$ & $0.110^{* * *}$ & $-0.050 * * *$ & $0.119^{* * *}$ & $0.322 * * *$ & $-0.038^{* *}$ & $0.176^{* * *}$ \\
\hline 2 Religion & $0.029 *$ & 1 & $0.906^{* * *}$ & $0.313^{* * *}$ & 0.023 & 0.011 & 0.002 & $0.075^{* * *}$ & $0.072^{* * *}$ & -0.001 & $0.057^{* * *}$ \\
\hline 3 Religion_A & $0.038^{* *}$ & $0.895^{* * *}$ & 1 & $-0.070 * * *$ & $0.035 *$ & -0.002 & 0.003 & $0.070^{* * *}$ & $0.066^{* * *}$ & -0.005 & $0.040 * *$ \\
\hline 4 Religion_N & -0.004 & $0.325^{* * *}$ & $-0.075^{* * *}$ & 1 & $-0.037^{* *}$ & 0.022 & 0.013 & 0.025 & 0.017 & 0.011 & 0.029 \\
\hline 5 Entrepreneur Gender & 0.007 & -0.007 & 0.008 & $-0.042^{* * *}$ & 1 & $0.101^{* * *}$ & $0.043 * *$ & $0.064^{* * *}$ & $0.100^{* * *}$ & 0.003 & $0.134^{* * *}$ \\
\hline 6 Entrepreneur Age & $0.037^{* *}$ & 0.007 & -0.006 & 0.018 & $0.124^{* * *}$ & 1 & $-0.059^{* * *}$ & $0.276^{* * *}$ & $0.228^{* * *}$ & -0.017 & $0.217^{* * *}$ \\
\hline 7 Largest & -0.024 & 0.005 & 0.006 & 0.009 & $0.029 *$ & $-0.045^{* * *}$ & 1 & 0.022 & $-0.147^{* * *}$ & -0.019 & $-0.155^{* * *}$ \\
\hline 8 Firm age & -0.013 & $0.061^{* * *}$ & $0.056^{* * *}$ & 0.014 & $0.080 * * *$ & $0.292^{* * *}$ & 0.004 & 1 & $0.306^{* * *}$ & 0.005 & 0.284 \\
\hline 9 Firm Size & $0.042 * *$ & $0.075^{* * *}$ & $0.066^{* * *}$ & 0.018 & $0.136^{* * *}$ & $0.227^{* * *}$ & $-0.138^{* * *}$ & $0.332^{* * *}$ & 1 & $-0.041^{* *}$ & $0.748^{* * *}$ \\
\hline 10 Cashholding & -0.015 & -0.010 & -0.010 & 0.011 & -0.006 & -0.014 & -0.016 & 0.003 & $-0.030 *$ & 1 & 0.002 \\
\hline 11 Log Sale & $-0.113^{* * *}$ & $0.067^{* * *}$ & $0.064^{* * *}$ & -0.000 & $0.132 * * *$ & $0.187^{* * *}$ & $-0.095^{* * *}$ & $0.336^{* * *}$ & $0.619 * * *$ & 0.015 & 1 \\
\hline
\end{tabular}

The symbols $* * * * *$, and ${ }^{*}$ indicate significance at the $1 \%, 5 \%$, and $10 \%$ level, respectively. Below the diagonal are Pearson correlations, and above the diagonal are Spearman correlations. 
Table 4. Regression results of entrepreneurs' religiosity on environmental investment.

\begin{tabular}{cccc}
\hline Dep. Eninvest & $\mathbf{( 1 )}$ & $\mathbf{( 2 )}$ & $\mathbf{( 3 )}$ \\
\hline \multirow{2}{*}{ Religion } & $0.132^{*}$ & $0.176^{*}$ & $0.182^{*}$ \\
& $(1.78)$ & $(1.81)$ & $(1.86)$ \\
\hline Largest & & -0.126 & -0.140 \\
& & $(-1.47)$ & $(-1.60)$ \\
\hline Firm age & & -0.024 & -0.020 \\
& & $(-0.40)$ & $(-0.32)$ \\
\hline Firm Size & & $0.332^{* * *}$ & $0.295^{* * *}$ \\
& & $(7.55)$ & $(6.50)$ \\
\hline \multirow{2}{*}{ Cashholding } & & -0.057 & -0.023 \\
& & $(-0.69)$ & $(-0.27)$ \\
\hline Log Sale & & $-0.278^{* * * *}$ & $-0.283^{* * *}$ \\
& & $(-7.54)$ & $(-7.25)$ \\
\hline Constant & $0.462^{* * *}$ & $3.721^{* * *}$ & $3.907^{* * *}$ \\
\hline Industry Fixed Effect & $(13.82)$ & $(7.95)$ & $(7.98)$ \\
Year Fixed Effect & $\mathrm{NO}$ & $\mathrm{NO}$ & YES \\
Obs. & 3682 & NO & YES \\
Adi_R ${ }^{2}$ & 0.001 & 0.055 & 3682 \\
\hline
\end{tabular}

The symbols *** and * indicate significance at the $1 \%$ and $10 \%$ level, respectively. We adjust the standard errors by correcting for simultaneous clustering by firm.

Table 5. Regression results of entrepreneurs' religiosity and entrepreneurs' age on environmental investment.

\begin{tabular}{|c|c|c|c|}
\hline Dep. Eninvest & (1) & (2) & (3) \\
\hline Entrepreneur Age & $\begin{array}{c}0.007^{* *} \\
(2.05)\end{array}$ & $\begin{array}{c}0.012 * * * \\
(2.96)\end{array}$ & $\begin{array}{c}0.009^{* *} \\
(2.28)\end{array}$ \\
\hline Religion $\times$ Entrepreneur Age & $\begin{array}{c}0.003 * \\
(1.75)\end{array}$ & $\begin{array}{c}0.004 * \\
(1.85)\end{array}$ & $\begin{array}{l}0.004 \text { * } \\
(1.90)\end{array}$ \\
\hline Largest & & $\begin{array}{l}-0.119 \\
(-1.39)\end{array}$ & $\begin{array}{l}-0.136 \\
(-1.54)\end{array}$ \\
\hline Firm age & & $\begin{array}{l}-0.063 \\
(-1.04) \\
\end{array}$ & $\begin{array}{l}-0.052 \\
(-0.82)\end{array}$ \\
\hline Firm Size & & $\begin{array}{c}0.327^{* * *} \\
(7.44)\end{array}$ & $\begin{array}{c}0.293^{* * *} \\
(6.47)\end{array}$ \\
\hline Cashholding & & $\begin{array}{l}-0.047 \\
(-0.57)\end{array}$ & $\begin{array}{l}-0.017 \\
(-0.21)\end{array}$ \\
\hline Log Sale & & $\begin{array}{c}-0.282 * * * \\
(-7.58)\end{array}$ & $\begin{array}{c}-0.286^{* * * *} \\
(-7.26)\end{array}$ \\
\hline Constant & $\begin{array}{c}0.130 \\
(0.794)\end{array}$ & $\begin{array}{c}3.343^{* * *} \\
(7.24)\end{array}$ & $\begin{array}{c}3.598^{* * *} \\
(7.46)\end{array}$ \\
\hline Industry Fixed Effect & $\mathrm{NO}$ & $\mathrm{NO}$ & YES \\
\hline Year Fixed Effect & NO & $\mathrm{NO}$ & YES \\
\hline Obs. & 3652 & 3652 & 3652 \\
\hline Adi_R $R^{2}$ & 0.002 & 0.058 & 0.081 \\
\hline
\end{tabular}

The symbols ***,**, and * indicate significance at the $1 \%, 5 \%$, and $10 \%$ level, respectively. We adjust the standard errors by correcting for simultaneous clustering by firm.

Table 6 presents the regression results of entrepreneur religiosity and entrepreneur gender on environmental investment, as specified in Model (3). As Table 6 shows, the coefficients of the interaction 
term (Religion $\times$ Entrepreneur Gender) are positive and significant in Columns (2) and (3). The results indicate that if a firm has a male entrepreneur, the level of firm environmental investment will be higher. In other words, the positive correlation between entrepreneur religiosity and firm environmental investment is strengthened for firms with male entrepreneurs, which verifies $\mathrm{H} 3 \mathrm{~b}$.

Table 6. Regression results of entrepreneurs' religiosity and entrepreneurs' gender on environmental investment.

\begin{tabular}{|c|c|c|c|}
\hline Dep. Eninvest & (1) & (2) & (3) \\
\hline Entrepreneur Gender & $\begin{array}{l}0.013 \\
(0.15)\end{array}$ & $\begin{array}{l}0.048 \\
(0.50)\end{array}$ & $\begin{array}{l}0.024 \\
(0.25)\end{array}$ \\
\hline $\begin{array}{c}\text { Religion } \times \text { Entrepreneur } \\
\text { Gender }\end{array}$ & $\begin{array}{l}0.117 \\
(1.46)\end{array}$ & $\begin{array}{l}0.150 * \\
(1.71)\end{array}$ & $\begin{array}{l}0.154 * \\
(1.74)\end{array}$ \\
\hline Largest & & $\begin{array}{l}-0.127 \\
(-1.62)\end{array}$ & $\begin{array}{c}-0.141 \text { * } \\
(-1.77)\end{array}$ \\
\hline Firm age & & $\begin{array}{l}-0.023 \\
(-0.42)\end{array}$ & $\begin{array}{l}-0.019 \\
(-0.34)\end{array}$ \\
\hline Firm Size & & $\begin{array}{c}0.332 * * * \\
(10.74)\end{array}$ & $\begin{array}{c}0.295^{* * *} \\
(8.89)\end{array}$ \\
\hline Cashholding & & $\begin{array}{l}-0.056 \\
(-0.67)\end{array}$ & $\begin{array}{l}-0.023 \\
(-0.27)\end{array}$ \\
\hline Log Sale & & $\begin{array}{c}-0.279 * * * \\
(-12.75)\end{array}$ & $\begin{array}{c}-0.284^{* * *} \\
(-12.50)\end{array}$ \\
\hline Constant & $\begin{array}{c}0.459 * * * \\
(5.95)\end{array}$ & $\begin{array}{c}3.712 \text { *** } \\
(12.83)\end{array}$ & $\begin{array}{c}3.904^{* * *} \\
(12.88)\end{array}$ \\
\hline Industry Fixed Effect & $\mathrm{NO}$ & $\mathrm{NO}$ & YES \\
\hline Year Fixed Effect & $\mathrm{NO}$ & $\mathrm{NO}$ & YES \\
\hline Obs. & 3672 & 3672 & 3672 \\
\hline Adi_R $R^{2}$ & 0.001 & 0.055 & 0.079 \\
\hline
\end{tabular}

The symbols ${ }^{* * *}$ and * indicate significance at the $1 \%$ and $10 \%$ level, respectively. We adjust the standard errors by correcting for simultaneous clustering by firm.

\subsubsection{Effects of Different Types of Religion on Firm Environmental Investment}

Table 7 presents the regression results of the effects of Asian religions and non-Asian religions on environmental investment, as specified in Model (4). As Table 7 shows, Asian religions are positively and significantly related to environmental investment, while non-Asian religions are not related to environmental investment. The regression results indicate that the positive association between entrepreneurs' religiosity and firm environmental investment is stronger for firms with entrepreneurs who adhere to an Asian religion, providing empirical evidence to support $\mathrm{H} 4$.

\subsection{Robustness Checks}

\subsubsection{Alternative Proxy for Religion}

We employed a robustness check by using alternative religiosity measures. CPES (2010) provided us the data of individual religious tendency, which means whether the private entrepreneurs adhered to a specific religion. If the entrepreneur had an individual religious tendency, Religion Tendency was assigned a value of 1 , and 0 otherwise. Table 8 presents the regression results of religious tendency on environmental investment. The coefficients of Religion Tendency are all significant at the $5 \%$ level in the three columns. The results presented in Table 8 illustrate that the positive correlation between entrepreneurs' religiosity and environmental investment is robust. 
Table 7. Effects of Asian vs. non-Asian religions on environmental investment.

\begin{tabular}{|c|c|c|c|}
\hline Dep. Eninvest & (1) & (2) & (3) \\
\hline Religion_A & $\begin{array}{c}0.181 \text { * } \\
(1.93)\end{array}$ & $\begin{array}{c}0.224^{* *} \\
(2.08)\end{array}$ & $\begin{array}{c}0.230 * * \\
(2.13)\end{array}$ \\
\hline Religion_N & $\begin{array}{l}-0.015 \\
(-0.08)\end{array}$ & $\begin{array}{l}-0.020 \\
(-0.10)\end{array}$ & $\begin{array}{l}-0.026 \\
(-0.13)\end{array}$ \\
\hline Largest & & $\begin{array}{l}-0.126 \\
(-1.47)\end{array}$ & $\begin{array}{l}-0.140 \\
(-1.59)\end{array}$ \\
\hline Firm Age & & $\begin{array}{l}-0.025 \\
(-0.42)\end{array}$ & $\begin{array}{l}-0.021 \\
(-0.34)\end{array}$ \\
\hline Firm Size & & $\begin{array}{c}0.331^{* * *} \\
(7.54)\end{array}$ & $\begin{array}{c}0.294^{* * *} \\
(6.49)\end{array}$ \\
\hline Cashholding & & $\begin{array}{l}-0.056 \\
(-0.68)\end{array}$ & $\begin{array}{l}-0.023 \\
(-0.27)\end{array}$ \\
\hline Log Sale & & $\begin{array}{c}-0.277^{* * *} \\
(-7.53)\end{array}$ & $\begin{array}{c}-0.282^{* * *} \\
(-7.24)\end{array}$ \\
\hline Constant & $\begin{array}{c}0.458^{* * *} \\
(14.55)\end{array}$ & $\begin{array}{c}3.710^{* * *} \\
(7.93)\end{array}$ & $\begin{array}{c}3.897^{* * *} \\
(7.97)\end{array}$ \\
\hline Industry Fixed Effect & $\mathrm{NO}$ & $\mathrm{NO}$ & YES \\
\hline Year Fixed Effect & $\mathrm{NO}$ & $\mathrm{NO}$ & YES \\
\hline Obs. & 3682 & 3682 & 3682 \\
\hline Adi_R $R^{2}$ & 0.001 & 0.056 & 0.080 \\
\hline
\end{tabular}

The symbols ***,**, and * indicate significance at the $1 \%, 5 \%$, and $10 \%$ level, respectively. We adjust the standard errors by correcting for simultaneous clustering by firm.

Table 8. Robustness checks using other religiosity variables.

\begin{tabular}{cccc}
\hline Dep. Eninvest & $\mathbf{( 1 )}$ & $\mathbf{( 2 )}$ & $\mathbf{( 3 )}$ \\
\hline \multirow{2}{*}{ Religion Tendency } & $0.370^{* *}$ & $0.423^{* *}$ & $0.437^{* *}$ \\
& $(2.24)$ & $(2.28)$ & $(2.29)$ \\
\hline \multirow{2}{*}{ Largest } & & -0.109 & -0.118 \\
& & $(-1.21)$ & $(-1.29)$ \\
\hline Firm Age & & -0.035 & -0.034 \\
& & $(-0.58)$ & $(-0.54)$ \\
\hline Firm Size & $0.309^{* * *}$ & $0.277^{* * *}$ \\
& & $(6.84)$ & $(5.86)$ \\
\hline \multirow{2}{*}{ Cashholding } & & -0.071 & -0.035 \\
& & $(-0.81)$ & $(-0.39)$ \\
\hline Log Sale & & $-0.248^{* * *}$ & $-0.251^{* * *}$ \\
& & $(-6.63)$ & $(-6.44)$ \\
\hline Constant & $0.453^{* * *}$ & $3.350 * * *$ & $3.517^{* * *}$ \\
Industry Fixed Effect & $(14.40)$ & $(7.01)$ & $(7.13)$ \\
Year Fixed Effect & $\mathrm{NO}$ & $\mathrm{NO}$ & YES \\
Obs. & $\mathrm{NO}$ & $\mathrm{NO}$ & YES \\
Adi_R ${ }^{2}$ & 3181 & 3181 & 3181 \\
\hline
\end{tabular}

The symbols ${ }^{* * *}$ and ${ }^{* *}$ indicate significance at the $1 \%$ and $5 \%$ level, respectively. We adjust the standard errors by correcting for simultaneous clustering by firm. 


\subsubsection{Effect of Different Types of Asian Religions}

Previous studies on religion have mostly focused on non-Asian religions and made comparisons among them. Our study further examines the difference between Buddhism and Taoism in Asian religions which, to our knowledge, has rarely been examined. If the entrepreneur adhered to Buddhism, Buddhism equaled 1, and 0 otherwise. If the entrepreneur adhered to Taoism, Taoism was assigned a value of 1 , and 0 otherwise. Table 9 presents the regression results for Buddhism and Taoism on environmental investment. Buddhism is positively and significantly related to environmental investment, while Taoism is not related to environmental investment. The results reveal that the positive correlation between Asian religions and firm environmental investment is mostly driven by Buddhism.

Table 9. Effects of Buddhism vs. Taoism on environmental investment.

\begin{tabular}{cccc}
\hline Dep. Eninvest & $\mathbf{( 1 )}$ & $\mathbf{( 2 )}$ & $\mathbf{( 3 )}$ \\
\hline \multirow{2}{*}{ Buddhism } & $0.169^{*}$ & $0.213^{* *}$ & $0.215^{* *}$ \\
& $(1.79)$ & $(1.97)$ & $(1.98)$ \\
\hline \multirow{2}{*}{ Taoism } & 0.451 & 0.500 & 0.587 \\
& $(0.87)$ & $(0.77)$ & $(0.94)$ \\
\hline Control & YES & YES & YES \\
Industry Fixed Effect & NO & NO & YES \\
Year Fixed Effect & NO & NO & YES \\
Obs. & 3682 & 3682 & 3682 \\
Adi_R $R^{2}$ & 0.002 & 0.056 & 0.080
\end{tabular}

The symbols ** and * indicate significance at the $5 \%$ and $10 \%$ level, respectively. We adjust the standard errors by correcting for simultaneous clustering by firm.

\subsubsection{Regression Based on a Sample That Excludes Firms Located in Tibetan Areas}

As Tibetans are generally affiliated with Buddhism, the influence of the subsample of firms located in Tibetan areas may have confounded our analysis. It is well known that most Tibetans are affiliated with Buddhism, and Tibetans make up a large proportion of Chinese people affiliated with Buddhism. In order to reduce the quantitative asymmetry between Asian religions and non-Asian religions, we excluded firms located in Tibetan areas from the whole sample. If the regression results are consistent to Table 7, it shows that our conclusions are robust. Thus, we excluded firms located in provinces where Tibetans gather, including Xizang, Qinghai, Gansu, Sichuan, and Yunnan, to re-examine our main tests. Table 10 presents the regression results based on the limited sample that excludes firms located in Tibetan areas. In Table 10, Religion and Religion_A both have significantly positive coefficients, suggesting that our results are robust.

\subsubsection{SLS Regression}

As the correlation between entrepreneurs' individual religiosity and firm environmental investment may be driven by reverse causality or potentially omitted variables, following the method of Hilary and Hui, we used a two-stage least squares (2SLS) approach to effectively solve the endogeneity problem [17]. Hilary and Hui used the level of county religiosity as their primary instrument [17]. Similarly, we proposed regional religiosity as an instrument variable. There are many Buddhist monasteries, Taoist temples, churches, and mosques distributed throughout China; thus, we chose the number of "famous religious sites" in the province in which the firm is located as an instrument. Our sample covered 669 famous religious sites that were given this honor by the United Front Work Department of the Central Committee of the CPC and State Administration for Religious Affairs in 2010. We constructed the variable Religion Site, which is the number of famous religious sites in each province, as our instrument variable. Obviously, Religion Site is related to entrepreneurs' religiosity but not related to environmental investment. Table 11 presents the regression results of the 2SLS model. 
Table 10. Regression based on the limited sample that excludes firms located in Tibetan areas.

\begin{tabular}{ccc}
\hline Dep. Eninvest & $\mathbf{( 1 )}$ & $\mathbf{( 2 )}$ \\
\hline Religion & $\begin{array}{c}0.134^{*} \\
(1.73)\end{array}$ & \\
\hline Religion_A & & $\begin{array}{c}0.188^{* *} \\
(2.29)\end{array}$ \\
\hline Religion_N & & -0.202 \\
& & $(-0.95)$ \\
\hline Control & YES & YES \\
Industry Fixed Effect & YES & YES \\
Year Fixed Effect & YES & YES \\
Obs. & 2715 & 2715 \\
Adi_R ${ }^{2}$ & 0.084 & 0.085 \\
\hline
\end{tabular}

The symbols $* *$ and $*$ indicate significance at the $5 \%$ and $10 \%$ level, respectively. We adjust the standard errors by correcting for simultaneous clustering by firm.

Table 11. Regression results of the 2SLS model.

\begin{tabular}{|c|c|c|}
\hline & First Stage & Second Stage \\
\hline & Religion & Eninvest \\
\hline \multicolumn{3}{|c|}{ Instrument } \\
\hline Religion Site & $\begin{array}{c}0.004^{* * * *} \\
(6.43)\end{array}$ & \\
\hline Instrumented Religion & & $\begin{array}{l}1.089 * \\
(1.69)\end{array}$ \\
\hline \multicolumn{3}{|c|}{ Predetermined variables } \\
\hline Largest & $\begin{array}{l}0.004 \\
(0.23)\end{array}$ & $\begin{array}{l}-0.135 \\
(-1.52)\end{array}$ \\
\hline Firm age & $\begin{array}{c}0.038^{* * * *} \\
(3.26)\end{array}$ & $\begin{array}{l}-0.053 \\
(-0.85)\end{array}$ \\
\hline Firm Size & $\begin{array}{l}0.012 * \\
(1.79)\end{array}$ & $\begin{array}{c}0.320^{* * *} \\
(7.30)\end{array}$ \\
\hline Cashholding & $\begin{array}{l}-0.007 \\
(-0.41)\end{array}$ & $\begin{array}{l}-0.055 \\
(-0.65)\end{array}$ \\
\hline Log Sale & $\begin{array}{c}-0.0003 \\
(-0.07)\end{array}$ & $\begin{array}{c}-0.280 * * * \\
(-7.55)\end{array}$ \\
\hline Constant & $\begin{array}{l}0.010 \\
(0.17)\end{array}$ & $\begin{array}{c}3.683^{* * *} \\
(7.96)\end{array}$ \\
\hline Industry Fixed Effect & YES & YES \\
\hline Year Fixed Effect & YES & YES \\
\hline Obs. & 3039 & 3039 \\
\hline Adi_R $R^{2}$ & 0.022 & 0.017 \\
\hline
\end{tabular}

The symbols ${ }^{* * *}$ and * indicate significance at the $1 \%$ and $10 \%$ level, respectively.

Religion Site is positively and significantly related to Religion in the first-stage regression results. We used the residual of the first-stage regression as Instrumented Religion. Instrumented Religion is the variable of Religion that is considered with the instrumented variable of Religion Site. Instrumented Religion excluded the effect of Religion Site. If it still has a positive effect on Eninvest, it shows that there is no endogenous effect between Religion and Eninvest. Table 11 shows that Instrumented Religion is positively and significantly related to Eninvest in the second-stage regressions. After regressing with a 2SLS model, we reached the same conclusion; entrepreneurs' individual religiosity is partially correlated to the environmental investment behaviors of companies. 


\section{Conclusions}

From CPES (2010), we accurately derived entrepreneurs' individual religiosity and thus solved the problem caused by proxy variables for religiosity. Based on upper echelons theory and self-worth orientation theory, we used the OLS and 2SLS models to investigate the influence of entrepreneurs' individual religiosity on firm environmental investment, and the moderating effect of other characteristics of entrepreneurs on the relationship between them. We found that entrepreneurs' individual religiosity is positively associated with a firm environmental investment, even excluding the influence of Tibetans' belief in Buddhism. We further found evidence that the positive association between entrepreneurs' religiosity and firm environmental investment is stronger for firms with entrepreneurs who are elder or male. We also comprehensively studied the effects of different types of religions on firm environmental investment. We found that the positive association between entrepreneurs' religiosity and firm environmental investment is stronger for firms with entrepreneurs who adhere to Asian religions and, with further analysis, that the positive correlation between Asian religions and firm environmental investment is mostly driven by Buddhism.

The results of our paper indicate that entrepreneurs' religiosity urges them to take environmental responsibility and strengthen firm environmental investment. Specifically, religious entrepreneurs' "environmental protection" attitude may be relatively closer to religious values than among nonreligious entrepreneurs, and their behaviors are highly consistent with religious value orientation. Our study has some practical implications. For government, informal institutions such as religion should be considered in environmental governance. For private firms, freedom of religion should be encouraged for all staff, especially owners or managers.

Author Contributions: Data curation, W.Z.; Formal analysis, S.Y. and W.Z.; Project administration, S.Y. All authors have read and agreed to the published version of the manuscript.

Funding: This work was supported by Fundamental Research Funds for the Central Universities under Grant 2017XKQY086.

Acknowledgments: The authors would like to thank the anonymous reviewer for suggestions that substantially improved the article. The authors acknowledge the Fundamental Research Funds for the Central Universities for their support.

Conflicts of Interest: The authors declare no conflict of interest.

\section{Appendix A}

Table A1. Variable definitions.

\begin{tabular}{cc}
\hline Variables & Definition \\
\hline Eninvest & The amount of environmental investment scaled by sales revenue in the current year times 100. \\
\hline Religion & A dummy variable that equals 1 if the private entrepreneurs have a religion, and 0 otherwise. \\
\hline Religion_A & $\begin{array}{r}\text { A dummy variable that equals } 1 \text { if the private entrepreneurs have an Asian religion, and 0 } \\
\text { otherwise. Asian religions include Buddhism and Taoism. }\end{array}$ \\
\hline Religion_N & $\begin{array}{c}\text { A dummy variable that equals } 1 \text { if the private entrepreneurs have a non-Asian religion, and } 0 \\
\text { otherwise. Non-Asian religions include Islam, Catholicism, and Christianity. }\end{array}$ \\
\hline Entrepreneur Age & The age of the private entrepreneurs. \\
\hline Entrepreneur Gender & A dummy variable that equals 1 if the private entrepreneur is male, and 0 otherwise. \\
\hline Largest & $\begin{array}{c}\text { A dummy variable, that equals } 1 \text { if the largest shareholding ratio exceeds } 50 \%, \text { and } 0 \text { otherwise. } \\
\text { The largest shareholder should be one person who may be the owner or manager of the firm. }\end{array}$ \\
\hline Firm age & The natural logarithm of years since the firm was registered. \\
\hline Firm Size & The natural logarithm of the number of employees. \\
\hline Cashholding & The cash and equivalents scaled by total assets. \\
\hline Log Sale & The natural logarithm of sales revenue. \\
\hline Industry & Industry dummy variable. \\
\hline Year & Year dummy variable. \\
\hline
\end{tabular}




\section{References}

1. Parsons, T. Structure and Process in Modern Societies; The Free Press: Glencoe, UK, 1960.

2. Wernerfelt, B. A resource-based view of the firm. Strat. Manag. J. 1984, 5, 171-180. [CrossRef]

3. Wood, D.J. Corporate Social Performance Revisited. Acad. Manag. Rev. 1991, 16, 691-718. [CrossRef]

4. Lundgren, T. A Real Options Approach to Abatement Investments and Green Goodwill. Environ. Resour. Econ. 2003, 25, 17-31. [CrossRef]

5. Lee, A.I.; Alm, J. The Clean Air Act Amendments and Firm Investment in Pollution Abatement Equipment. Land Econ. 2004, 80, 433. [CrossRef]

6. Kassinis, G.; Vafeas, N. Stakeholder Pressures and Environmental Performance. Acad. Manag. J. 2006, 49, 145-159. [CrossRef]

7. Blanco, E.; Rey-Maquieira, J.; Lozano, J. The economic impacts of voluntary environmental performance of firms: A critical review. J. Econ. Surv. 2009, 23, 462-502. [CrossRef]

8. Haller, S.A.; Murphy, L. Corporate expenditure on environmental protection. Environ. Resour. Econ. 2012, 51, 277-296. [CrossRef]

9. Magnani, L.; Tubb, A. Green R\&D, Technology Spillovers, and Market Uncertainty: An Empirical Investigation. Land Econ. 2012, 88, 685-709.

10. Ramus, C.A.; Steger, U. The Roles of Supervisory Support Behaviors and Environmental Policy in Employee "Ecoinitiatives" at Leading-Edge European Companies. Acad. Manag. J. 2000, 43, 605-626.

11. Cordano, M.; Frieze, I.H. Pollution reduction preferences of u.s. environmental managers: Applying ajzen's theory of planned behavior. Acad. Manag. J. 2000, 43, 627-641.

12. Wei, L.; Ling, Y. CEO characteristics and corporate entrepreneurship in transition economies: Evidence from China. J. Bus. Res. 2015, 68, 1157-1165. [CrossRef]

13. Park, C.L. Religiousness/Spirituality and Health: A Meaning Systems Perspective. J. Behav. Med. 2007, 30, 319-328. [CrossRef] [PubMed]

14. Miller, A.S. Going to Hell in Asia: The Relationship between Risk and Religion in a Cross Cultural Setting. Rev. Relig. Res. 2000, 42, 5. [CrossRef]

15. Cai, Y.; Kim, Y.; Li, S.; Pan, C. Tone at the top: CEOs' religious beliefs and earnings management. J. Bank. Financ. 2019, 106, 195-213. [CrossRef]

16. Williamson, O.E. The New Institutional Economics: Taking Stock, Looking Ahead. J. Econ. Lit. 2000, 38, 595-613. [CrossRef]

17. Hilary, G.; Hui, K.W. Does religion matter in corporate decision making in America? J. Financ. Econ. 2009, 93, 455-473. [CrossRef]

18. Du, X.; Wei, J.; Du, Y.; Feng, W.; Quan, Z. Religion, the nature of ultimate owner, and corporate philanthropic giving: Evidence from China. J. Bus. Ethics 2014, 123, 235-256. [CrossRef]

19. Jiang, F.; Jiang, Z.; Kim, K.A.; Zhang, M. Family-firm risk-taking: Does religion matter? J. Corp. Financ. 2015, 33, 260-278. [CrossRef]

20. Wang, Q.; Lin, X. Does religious beliefs affect economic growth? Evidence from provincial-level panel data in China. China Econ. Rev. 2014, 31, 277-287. [CrossRef]

21. Ying, Z.; Liu, S.; Bao, S.; Zhou, J. Religious diversity and regional development in China. China Econ. Rev. 2017, 46, 1-9. [CrossRef]

22. Nyborg, H. The intelligence-religiosity nexus: A representative study of white adolescent Americans. Intelligence 2009, 37, 81-93. [CrossRef]

23. Reeve, C. Expanding the g-nexus: Further evidence regarding the relations among national IQ, religiosity and national health outcomes. Intelligence 2009, 37, 495-505. [CrossRef]

24. Du, X.; Jian, W.; Zeng, Q.; Du, Y. Corporate environmental responsibility in polluting industries: Does religion matter? J. Bus. Ethics 2014, 124, 485-507. [CrossRef]

25. Hambrick, D.C.; Mason, P.A. Upper Echelons: The Organization as a Reflection of Its Top Managers. Acad. Manag. Rev. 1984, 9, 193-206. [CrossRef]

26. Iannaccone, L.R. Introduction to the economics of religion. J. Econ. Lit. 1998, 36, 1465.

27. Buchholz, R.A. An empirical study of contemporary beliefs about work in American society. J. Appl. Psychol. 1978, 63, 219-227. [CrossRef]

28. Kahalas, H.; Groves, D.L. An exploration of graduate business students' values. J. Appl. Psychol. 1979, 6, 18. 
29. Trevino, L.K. Ethical Decision Making in Organizations: A Person-Situation Interactionist Model. Acad. Manag. Rev. 1986, 11, 601-617. [CrossRef]

30. Manner, M.H. The Impact of CEO Characteristics on Corporate Social Performance. J. Bus. Ethic 2010, 93, 53-72. [CrossRef]

31. Boulouta, I. Hidden connections: The link between board gender diversity and corporate social performance. J. Bus. Ethic 2013, 113, 185-197. [CrossRef]

32. Williams, R.J. Women on Corporate Boards of Directors and their Influence on Corporate Philanthropy. J. Bus. Ethic 2003, 42, 1-10. [CrossRef]

33. Bowen, D.D.; Hisrich, R.D. The Female Entrepreneur: A Career Development Perspective. Acad. Manag. Rev. 1986, 11, 393-407. [CrossRef]

34. Tang, G.; Li, L.; Wu, D. Environmental regulation, industry attributes and corporate environmental investment. Account. Res. 2013, 6, 83-89. [CrossRef]

35. Shen, N.; Su, J. Religion and succession intention-Evidence from Chinese family firms. J. Corp. Financ. 2017, 45, 150-161. [CrossRef]

(C) 2020 by the authors. Licensee MDPI, Basel, Switzerland. This article is an open access article distributed under the terms and conditions of the Creative Commons Attribution (CC BY) license (http://creativecommons.org/licenses/by/4.0/). 